\title{
Penerapan Pendekatan Kontekstual untuk Meningkatkan Hasil Belajar Matematika
}

\author{
Ni Luh Rai* \\ Sekolah Dasar Negeri 6 Tianyar, Kecamatan Kubu, Kabupaten Karangasem, Bali, Indonesia
}

A R T I C L E I N F O

Article history:

Received 19 February

2019

Received in revised form

30 March 2019

Accepted 10April 2019

Available online 20 May 2019

Kata Kunci:

hasil belajar, pendekatan pembelajaran kontekstual

Keywords:

Learning outcomes, contextual learning approaches

\begin{abstract}
A B S T R A K
Penelitian ini bertujuan untuk meningkatkan hasil belajar matematika siswa kelas I semester I SD Negeri 6 Tianyar melalui penerapan pendekatan pembelajaran kontekstual. Penelitian ini menggunakan pendekatan penelitian tindakan kelas dengan desain siklus model Kemmis dan Taggart. Partisipan yang menjadi subjek penelitian ini adalah siswa kelas I SD Negeri 6 Tianyar yang berjumlah 14 orang. Pembelajaran dilakukan dalam dua siklus tindakan selama dua kali pertemuan. Data dikumpulkan menggunakan metode tes. Data hasil belajar berupa skor selanjutnya dianalisis, dievaluasi, dan direfleksikan. Metode analisis data yang digunakan adalah metode analisis statistik deskriptif. Hasil penelitian menunjukkan bahwa penerapan model pembelajaran kontekstual dapat meningkatkan hasil belajar matematika siswa. Skor hasil belajar pada siklus I menunjukkan rerata 52,14\% dan pada akhir siklus I skor hasil belajar menunjukkan rerata 60 Dibandingkan dengan pencapaian skor hasil belajar siklus I, ternyata skor hasil belajar pada siklus II mengalami peningkatan sebesar $65 \%$. Walaupun terjadi peningkatan hasil belajar matematika siswa, namun masih banyak kendala yang muncul selama proses pembelajaran. Berkat keuletan peneliti dan bantuan dari berbagai pihak, berbagai hambatan dan kendala itu dapat di atasi dengan baik sehingga pelaksanaan tindakan dapat berjalan sesuai rencana
\end{abstract}

A B S T R A C T

This study aims to improve the mathematics learning outcomes of class I students of the first semester of Tianyar 6 Elementary School through the application of a contextual learning approach. This study uses a classroom action research approach with cycle design models Kemmis and Taggart. Participants who were the subjects of this study were 14th grade students of SD 6 Tianyar. Learning is carried out in two cycles of action for two meetings. Data was collected using the test method. Data on learning outcomes in the form of further scores are analyzed, evaluated, and reflected. The data analysis method used is descriptive statistical analysis method. For the level of mastery learning using the standard 60\%. This is in accordance with the standards set at school. The results of the study show that the application of the contextual learning model can improve students' mathematics learning outcomes. The score of learning outcomes in the first cycle showed an average of $52.14 \%$ and at the end of the cycle I the score of learning outcomes showed an average of 60 Compared with the achievement of the score of learning outcomes in the first cycle, it turned out that the learning outcomes in the second cycle increased by 65\%. Although there was an increase in students' mathematics learning outcomes, there were still many obstacles that arose during the learning process. Thanks to the resilience of researchers and assistance from various parties, various obstacles and constraints can be overcome properly so that the implementation of actions can go according to plan 


\section{Pendahuluan}

Salah satu upaya dalam rangka meningkatkan mutu sumber daya manusia pada era globalisasi yang penuh dengan persaingan dan tuntutan profesional dalam bidang ketenagakerjaan adalah melalui pendidikan. Dalam dunia pendidikan pengelolaan kegiatan pembelajaran harus mendapatkan perhatian yang serius. Kelancaran proses pembelajaran didukung oleh banyak faktor. Di antaranya menurut Nochi dan Nasution (1994) " Faktor-faktor yang mempengaruhi terhadap proses pembelajaran adalah faktor eksteren (luar) dan faktor intern (dalam)". Faktor ekstern yang dimaksud adalah faktor lingkungan peserta didik dan faktor instrumental. Faktor intern meliputi kecerdasan, bakat, minat, motivasi, dan kemampuan kognitif.

Dalam Kurikulum Pendidikan Dasar pada pengembangan keterampilan baca, tulis, dan hitung mencerminkan bahwa materi pembelajaran matematika sangat penting terutama dalam berhitung. Oleh karena itu pelajaran matematika perlu mendapat perhatian yang serius, demikian pula hasil belajar dalam pembelajaran matematika untuk terus ditingkatkan.

Menurut Bruner (dalam Hudoyo,1990:48) belajar matematika adalah belajar mengenai konsepkonsep dan struktur-struktur matematika yang terdapat di dalam materi yang dipelajari, serta mencari hubungan antara konsep-konsep dan struktur-struktur matematika itu. Matematika berfungsi mengembangkan kemampuan menghitung, mengukur, menemukan dan menggunakan rumus matematika yang dapat menunjang pemahaman konsep siswa kaitannya dalam kehidupan sehari-hari (Supriyanto, 2014). Menurut Flora (2012) mempelajari matematika adalah penting karena dalam kehidupan sehari-hari, kita tidak boleh mengelak dari aplikasi matematika bukan itu saja matematika juga mampu mengembangkan kesadaran tentang nilai-nilai yang secara esensial. Siswa harus dapat menemukan keteraturan dengan cara mengotak-atik bahan-bahan yang berhubungan dengan keteraturan intuitif yang sudah dimiliki siswa. Dengan demikian siswa dalam belajar, haruslah terlibat aktif mentalnya agar dapat mengenal konsep dan struktur yang tercakup dalam bahan yang sedang dibicarakan, anak akan memahami materi yang harus dikuasainya itu. Ini menunjukkan bahwa materi yang mempunyai suatu pola atau struktur tertentu akan lebih mudah dipahami dan diingat anak. Dalam setiap kesempatan, pembelajaran matematika hendaknya dimulai dengan pengenalan masalah yang sesuai dengan situasi (contextual problem). Dengan mengajukan masalah kontekstual, peserta didik secara bertahap dibimbing untuk menguasai konsep matematika. Untuk meningkatkan keefektifan pembelajaran, sekolah diharapkan menggunakan teknologi informasi dan komunikasi seperti komputer, alat peraga, atau media lainnya.

Dalam kegiatan proses belajar, anak sebaiknya diberi kesempatan memanipulasi benda-benda atau alat peraga yang dirancang secara khusus dan dapat diotak-atik oleh siswa dalam memahami suatu konsep matematika. Melalui alat peraga yang ditelitinya itu, anak akan melihat langsung bagaimana keteraturan dan pola struktur yang terdapat dalam benda yang sedang diperhatikannya itu. Keteraturan tersebut kemudian oleh anak dihubungkan dengan intuitif yang telah melekat pada dirinya.

Berdasarkan observasi awal yang dilakukan di kelas I SD Negeri 6 tahun ajaran 2017/2018 semester I ditemukan bahwa pelajaran matematika dipandang pelajaran yang kurang menarik dan sulit dipelajari oleh siswa. Minat anak mempelajari matematika sangat rendah. Kemampuan siswa dalam mengerjakan soal-soal matematika sangat rendah. Hal ini dapat dilihat pada hasil ulangan formatif dan ulangan sumatif tiap tahun tidak mengalami peningkatan, rata-ratanya selalu di bawah $60 \%$.

Berdasarkan observasi awal dapat diidentifikasi masalah sebagai faktor penyebab kurang meratanya hasil belajar siswa adalah sebagai berikut. (1)siswa kurang memahami tujuan dan manfaat pembelajaran matematika dalam kehidupan sehari-hariya, (2) dalam menyelesaikan masalah siswa hanya berorientasi pada rumus-rumus hafalan yang ada di buku paket, (3) pembelajaran yang diikuti siswa kurang aplikatif terhadap lingkungan, utamanya lingkungan siswa, sehingga pembelajaran membosankan, kendatipun siswa memahami materi pembelajaran namun sifatnya sementara dan mudah dilupakannya, (4) pembelajaran yang diikuti siswa terlalu kental dengan aturan guru, sehingga siswa tidak dapat belajar secara demokratis. Akibatnya, intelektual siswa tidak dapat berkembang sejalan dengan pertumbuhan biologisnya, siswa selalu disalahkan bila mengunakan caranya sendiri dan berseberangan dengan cara yang diinstruksikan guru dalam menyelesikan masalah, akhirnya siswa menjadi tidak percaya diri.

Kegiatan belajar yang telah dilakukan oleh guru selama ini masih bersifat pendekatan yang tradisional di mana proses pembelajaran yang berlangsung selama ini adalah sebagai berikut. (1) Guru kurang menggunakan media yang cukup untuk membuat siswa memahami materi pembelajaran, (2) Guru lebih menekankan hasil belajar secara kuantitas dengan cepat ketimbang hasil belajar secara kualitas, (3) Pemilihan strategi pembelajaran yang kurang tepat, sehingga tidak dapat merangsang siswa untuk belajar secara optimal, (3) Guru kurang mengkaitkan permasalahan yang kontekstual yang dialami langsung oleh siswa dalam kehidupan sehari-hari 
Bertolak dari latar belakang tersebut maka guru perlu melakukan suatu tindakan agar hasil belajar matematika siswa kelas I SD Negeri 6 Tianyar bisa ditingkatkan. Guru sebagai pelaksana pendidikan di kelas harus mampu melakukan suatu perubahan di kelas seperti menghadirkan situasi dunia nyata di kelas dengan memanfaatkan lingkungan sekitar sebagai media pembelajaran. Ada kecenderungan dewasa ini untuk kembali pada pemikiran bahwa anak akan belajar lebih baik jika lingkungan diciptakan alamiah. Belajar akan lebih bermakna jika 'anak mengalami' apa yang dipelajarinya, bukan 'mengetahui'-nya. Pembelajaran yang berorieritasi target penguasaan materi terbukti berhasil dalam kompetisi 'mengingat' jangka pendek, tetapi gagal dalam membekali anak memecahkm persoalan dalam kehidupan jangka panjang.

Pendekatan pembelajaran kontekstual memberikan peluang yang cukup besar untuk meningkatkan hasil belajar Matematika siswa kelas I SD Negeri 6 Tianyar. Pendekatan kontekstual (Contextual Teaching and Learning) merupakan konsep belajar yang membantu guru mengaitkan antara materi yang diajarkannya dengan situasi dunia nyata siswa dan mendorong siswa membuat hubungan antara pengetahuan yang dimilikinya dengan penerapannya dalam kehidupan mereka sebagai anggota keluarga dan masyarakat"(Nurhadi, dkk, 2004:4). Dengan konsep itu, hasil pembelajaran dihadapkan lebih bermakna bagi siswa. Proses pembelajaran berlangsung alamiah dalam bentuk kegiatan siswa bekerja dan mengalami, bukan transfer pengetahuan dari guru ke siswa. Strategi pembelajaran lebih dipentingkan dari pada hasil.

Dalam konteks itu siswa perlu mengerti apa makna belajar, apa manfaatnya, dalam status apa mereka, dan bagaimana mencapainya. Mereka sadar bahwa yang mereka pelajari berguna bagi hidupnya nanti. Mereka mempelajari apa yang bermanfaat bagi dirinya dan berupaya menggapainya. Dalam upaya itu, mereka memerlukan guru sebagai pengarah dan pembimbing.

Dalam kelas kontekstual, tugas guru adalah membantu siswa mencapai tujuannya. Maksudnya, guru lebih banyak berurusan dengan strategi daripada memberi informasi. Tugas guru mengelola kelas sebagai sebuah tim yang bekerja bersama untuk menemukan sesuatu yang baru bagi anggota kelas (siswa). Sesuatu yang baru datang dari 'menemukan sendiri', bukan dari 'apa kata guru'. Begitulah peran guru di kelas yang dikelola dengan pendekatan kontekstual. Kontekstual hanya sebuah strategi pembelajaran. Seperti halnya strategi pembelajaran yang lain, kontekstual dikembangkan dengan tujuan agar pembelajaran berjalan lebih produktif dan bermakna. Pendekatan kontekstual dapat dijalankan tanpa harus mengubah kurikulum dan tatanan yang ada.

Dengan pendekatan pembelajaran kontekstual, diharapkan hasil belajar matematika siswa dapat ditingkatkan. Olek karena itu penulis tertarik untuk melakukan suatu penelitian tindakan kelas (PTK) dengan judul "Penerapan Pendekatan Kontekstual Untuk Meningkatkan Hasil Belajar Matematika Kelas I Sekolah Dasar Negeri 6 Tianyar Kecamatan Kubu Tahun Pelajaran 2017/2018

\section{Metode}

Penelitian dilaksanakan pada bulan Juli 2017 sampai bulan Desember 2017 tahun Pelajaran 2017/2018 Penelitian dilaksanakan sesuai dengan jadwal kurikuler sekolah. Subjek penelitian dalam Penelitian Tindakan Kelas ini adalah siswa kelas 1 Sekolah Dasar Negeri 6 Tianyar semester I tahun ajaran 2017/2018. Jumlah siswa sebanyak 14 orang terdiri atas 8 orang siswa laki-laki dan 6 orang siswa perempuan. Penelitian ini dilakukan dengan menggunakan metode Penelitian Tindakan Kelas, menurut Kemmis dan Mc.Taggart (dalam Suyanto, dkk, 1997). Pelaksanaan penelitian ini direncanakan dalam 2 (dua ) siklus. Tiap siklus terdiri atas 4 (empat) tahap kegiatan, yakni Perencanaan, Tindakan, Observasi/Evaluasi, dan Refleksi.

Kegiatan yang dilakukan dalam penelitian merupakan kegiatan berdaur. Dalam penelitian tindakan kelas ini menggunakan variabel hasil belajar dan pendekatan pembelajaran kontekstual. Bila pendekatan pembelajaran kontekstual dapat diterapkan secara efektif dalam pembelajaran matematika, diyakini dapat meningkatkan hasil belajar. Dengan pembelajaran kontekstual siswa akan lebih memahami materi pembelajaran, karena siswa belajar mengalami, belajar pada dunia nyata, belajar mengkonstruksi pengetahuan sendiri, belajar menemukan, dan belajar bekerjasama melalui masyarakat belajar (learning society). Adapun tahapan dalam penelian ini terdapat dua siklus dengan tahapannya yaitu perencanaan tindakan, pelaksanaan tindakan, tahap observasi/evaluasi, dan tahap refleksi. Instrumen penelitian yang digunakan adalah soal-soal tes. Soal-soal tes yang digunakan adalah soal tes uraian. Jumlah item soal yang digunakan adalah 10 item, dengan bobot 1 tiap item soal. Metode analisis data yang digunakan adalah metode analisis statistik deskriptif. 


\section{Hasil dan Pembahasan}

Kondisi Awal dan Data Pra Siklus

Kondisi Awal

Sekolah Dasar Negeri 6 Tianyar terletak di Desa Tianyar Kecamatan Kubu, Kabupaten Karangasem. Letak geografis sekolah yaitu di Dusun Darmawinangun termasuk katagori jarak jauh antara rumah siswa yang paling jauh ke sekolah kira-kira $2 \mathrm{Km}$. Keadaan ekonomi siswa mayoritas kelas ekonomi menengah ke bawah, ke-14 siswa orang tuanya bekerja sebagai petani, orang tuanya tidak memiliki penghasilan tetap. Mengenai proses pembelajaran setiap hari berdasarkan pengamatan sudah berjalan dengan baik. Namun dalam pelaksanaan penilaian, baik formatif maupun sumatif skor hasil belajarnya kurang memuaskan atau mencapai rata-rata hasil belajar di bawah 60\%. Guru-guru tidak ada usaha untuk mengadakan pembelajaran perbaikan terhadap kelompok atau individu siswa yang mengalami masalah belajar.

Guru selalu beranggapan bahwa proses pembelajaran yang dirancang dan dilaksanakan selalu benar, tidak mau mengadakan refleksi diri untuk menemukan kelemahan atau kesalahan dalam pemilihan strategi pembelajaran, tidak ada motivasi guru untuk mengusahakan solusinya agar siswa dapat belajar secara optimal agar siswa tidak lagi dijadikan sasaran kesalahan oleh guru dengan tuduhan tidak pernah belajar.

a. Pra siklus

Sebelum mengadakan tindakan, Peneliti terlebih dahulu mengadakan tes awal(pre-test). Hal ini dilahukan untuk mengetahui pengetahuan awal siswa mengenai materi bilangan pecahan. Setelah dilakukan penskoran terhadap hasil tes awal, diperoleh sebaran skor sebagai berikut.

Tabel 1. Data Skor Hasil Belajar Matematika Siswa Kelas I SD Negeri 6 Tianyar Tahun 2017/2018, Pra Siklus

\begin{tabular}{|c|c|c|c|c|}
\hline \multirow{2}{*}{ No } & No & \multicolumn{3}{|c|}{ Skor Hasil Belajar } \\
\hline & Kode Siswa & Pra Siklus & Siklus I & Siklus II \\
\hline 1. & 001 & 30 & & \\
\hline 2. & 002 & 30 & & \\
\hline 3. & 003 & 60 & & \\
\hline 4. & 004 & 40 & & \\
\hline 5. & 005 & 30 & & \\
\hline 6. & 006 & 60 & & \\
\hline 7. & 007 & 70 & & \\
\hline 8. & 008 & 50 & & \\
\hline 9. & 009 & 50 & & \\
\hline 10. & 010 & 60 & & \\
\hline 11. & 011 & 60 & & \\
\hline 12. & 012 & 70 & & \\
\hline 13 & 013 & 60 & & \\
\hline 14 & 014 & 60 & & \\
\hline \multicolumn{2}{|r|}{ Jumlah } & 730 & & \\
\hline & Rata-Rata & 52,14 & & \\
\hline & Skor tertinggi & 70 & & \\
\hline & Skor terendah & 30 & & \\
\hline
\end{tabular}

b. Hasil Penelitian Pada Siklus I

Perencanaan tindakan siklus I terdiri atas: (1) menetapkan pokok bahasan yang akan diajarkan, yakni "Pecahan (2) mengidentifikasi dan menganalisis standar kompetensi, kompetensi dasar, dan indikator, (3) membuat bahan ajar, (4) menyiapkan media pembelajaran, (5) menyusun rencana pelaksanaan pembelajaran, dan (6) menyusun instrumen penilaian pembelajaran.

Hal-hal pokok yang dilaksanakan pada tahap tindakan siklus I ini adalah menerapkan pembelajaran kontekstual yang telah disusun dalam RPP dengan kegiatan sebagai berikut. 1) kegiatan awal, guru memotivasi siswa agar bertanya yang berkaitan dengan materi yang akan diajarkan. Tujuan kegiatan ini adalah menggali informasi, membangkitkan respon siswa terhadap materi pembelajaran, memfokuskan perhatian siswa pada sesuatu yang diinginkan guru, 2) guru mendemonstrasikan cara menentukan bilangan pecahan, 3) mengelompokkan siswa ke dalam beberapa kelompok yang heterogen (4 orang tiap kelompok), 4) mengajak siswa untuk mengkonstruksi dan menemukan pengetahuan sendiri dan 
bekerjasama dengan temannya melalui kegiatan memotong benda-benda yang ada dekat dengan anak sebagai media atau sengaja dipersiapkan, 5) siswa mengadakan diskusi kelompok untuk membahas hasil kerja kelompok, 6) masing-masing kelompok mengkomunikasikan hasil kerjanya di depan kelas, 7) melalui bimbingan guru, siswa menyimpulkan materi pembelajaran, 8) siswa mengadakan refleksi pembelajaran dengan kegiatan siswa menanggapi kegiatan pembelajaran yang telah dikuti, 9) Guru memberikan tes kepada masing-masing siswa untuk mengetahui penguasaan siswa terhadap materi pembelajaran.

Pada tahap observasi terhadap pelaksanaan tindakan. Tujuan diadakannya observasi adalah untuk mengetahui langkah-langkah pembelajaran yang mana patut dipertahankan, diperbaiki, atau dihilangkan dalam proses pembelajaran selanjutnya, sehingga hasil belajar matematika siswa kelas I SDN 6 Tianyar benar-benar dapat meningkat. Kegiatan siswa juga sangat perlu diobservasi untuk melihat aktivitas fisik maupun mentalnya dalam belajar. Setelah diadakan pengamatan dilanjutkan dengan pemberian tes hasil belajar kepada masing-masing siswa untuk mendapatkan data tentang hasil belajar.

Setelah dilakukan penskoran terhadap hasil tes belajar tersebut, diperoleh sebaran skor sebagai berikut.

Tabel 2.Data Skor Hasil Belajar Matematika Siswa Kelas I SD Negeri 6 Tianyar Tahun 2017/2018, Siklus I

\begin{tabular}{ccc}
\hline No & No Kode Siswa & Skor \\
\hline 1. & 001 & 50 \\
2. & 002 & 40 \\
3. & 003 & 70 \\
4. & 004 & 70 \\
5. & 005 & 50 \\
6. & 006 & 60 \\
7. & 007 & 70 \\
8. & 008 & 50 \\
9. & 009 & 60 \\
10. & 010 & 60 \\
11. & 011 & 60 \\
12. & 012 & 80 \\
13 & 013 & 60 \\
14 & 014 & 60 \\
& Jumlah & 840 \\
& Rata-Rata & 60 \\
& Skor tertinggi & 80 \\
& Skor terendah & 40 \\
\hline
\end{tabular}

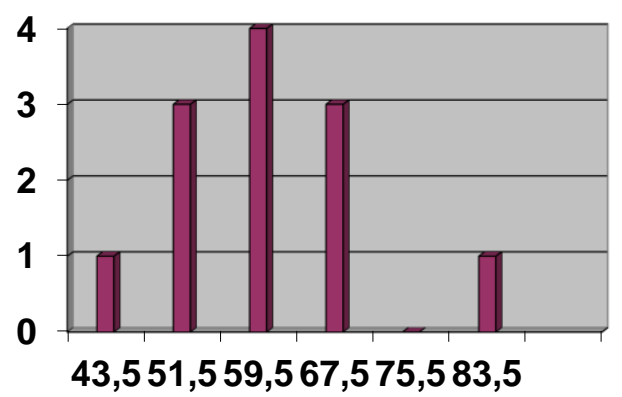

Gambar 1. Grafik Polygon Hasil Belajar Matematika Siklus I

Berdasarkan penyajian grafik di atas dapat dianalisis bahwa Me $<$ M $<$ Mo atau 59,5 $<60,17<$ 61,5. Bentuk kurva di atas menunjukkan kurva juling negatif, yang artinya sebagian besar skor hasil belajar matematika kelas I cenderung tinggi atau di atas rata-rata.

Mengkaji hasil belajar matematika siswa kelas I pada siklus I, dapat dideskripsikan yaitu skor hasil belajar yang diperoleh dari 14 orang siswa adalah satu orang siswa memperoleh skor pada interval 80 89 berada pada kategori baik, tiga orang siswa memperoleh skor pada interval 65-79 berada pada 
kategori cukup, enam orang siswa memperoleh skor pada interval 55-64 berada pada kategori kurang, dan empat orang memperoleh skor pada interval 0 - 56 berada pada kategori sangat kurang. Sedangkan tingkat hasil belajar rata-rata siswa kelas I siklus I sebesar 58,17 ternyata berada dalam kategori kurang. Mencermati hasil analisis data hasil belajar Matematika siswa kelas I SDN 6 Tianyar dilakukan refleksi terhadap penggunaan pendekatan pembelajaran kontekstual $\mathrm{d}$ 40 selanjutnya Matematika.

Berdasarkan hasil belajar pada siklus I sudah tampak adanya peningkatan hasil belajar matematika siswa kelas I, hal ni dapat diamati dari perolehan skor rata-rata hasil belajar matematika dari pra siklus hingga pelaksanaan tindakan pada siklus I. Setelah diadakan refleksi terhadap hasil penelitian siklus I, diputuskan untuk mengadakan perbaikan pada kelemahan-kelemahan yang terjadi dalam pembelajaran. Kelemahan-kelemahan yang ditemui dalam pelaksanaan tindakan siklus I antara lain: (1) siswa masih bingung menentukan pecahan senilai maupun urutan pecahan, (2) Siswa kurang berani menyampaikan pertanyaan dalam kegiatan tanyajawab, (3) siswa kurang mampu menggunakan waktu secara efektif dalam kegiatan menemukan, Berdasarkan kendala tersebut di atas diputuskan untuk memperbaiki beberapa masalah pada pembelajaran siklus II. Perbaikan yang dilakukan antara lain: (1) memberikan penjelasan disertai penggunaan media yang lebih banyak dalam belajar, (2) memotivasi siswa agar mau mengungkapkan gagasannya baik melalui bertanya, menjawab pertanyaan teman atau guru, dan menanggapi suatu masalah melalui pertanyaan-pertanyaan terbuka, (3) memantau dan membimbing siswa dalam kegiatan menemukan, bila siswa mengalami masalah atau kemacetan akan cepat termotivasi, (4) mengadakan bimbingan yang lebih kepada kelompok siswa yang mengalami kemacetan dalam melakukan percobaan. Selanjutnya dilakukan persiapan pelaksanaan tindakan pada siklus II guna meningkatkan hasil belajar matematika pada siklus II.

\section{c. Hasil Penelitian Siklus II}

Berdasarkan refleksi yang telah dilakukan pada siklus I terhadap kelemahan-kelemahan yang terjadi dalam pelaksanaan tindakan dan kelemahan-kelemahan tersebut sangat perlu diadakan perbaikan pada pelaksanaan tindakan siklus II. Adapun kegiatan yang dilakukan pada siklus II adalah sebagai berikut. Perencanaan terdiri atas: (1) menetapkan pokok bahasan yang akan diajarkan, yakni "Bilangan pecahan," (2) mengidentifikasi dan menganalisis standar kompetensi, kompetensi dasar, dan indikator, (3) membuat bahan ajar, (4) menyiapkan media pembelajaran, (5) menyusun rencana pelaksanaan pembelajaran, dan (6) menyusun instrumen penilaian pembelajaran.

Pada tahap ini dilakukan kegiatan sebagai berikut. (1) kegiatan pendahuluan, terutama menciptakan suasana awal pembelajaran untuk memotivasi siswa agar dapat memfokuskan perhatian pada materi pembelajaran melalui pertanyaan. Hal pokok pada kegiatan pendahuluan adalah merangsang dan membangkitkan pengetahuan awal siswa serta memfokuskan diri pada materi yang akan dipelajari, (2) kegiatan inti, kegiatan ini memfokuskan pada kegiatan-kegiatan yang bertujuan untuk meningkatkan hasil belajar siswa melalui penggunaan pendekatan pembelajaran kontekstual yang lebih efektif dalam pembelajaran matematika di kelas I. Guru memotivasi siswa untuk menanyakan sesuatu yang berkaitan dengan materi pembelajaran yang bertujuan untuk merangsang dan menggali pengetahuan awal siswa, Guru memodelkan cara menggunakan media dalam penjumlahan pecahan maupun pengurangan pecahan (aspek pemodelan), membagi siswa menjadi beberapa kelompok dengan komposisi anggota kelompok heterogen di bidang kemampuan akademis (pembentukan masyarakat belajar), membagikan model lingkaran yang digunakan sebagai media bilangan pecahan. Guru memberikan bimbingan kepada masingmasing kelompok supaya tidak terjadi kemacetan dalam pelaksanaan tugas pembelajaran, masing-masing kelompok menyusun dan mengkomunikasikan hasil kerja di depan kelas (aspek konstruktivis dan menemukan), membimbing siswa untuk menyimpulkan materi pelajaran, selanjutnya memberikan penghargaan dan penguatan-penguatan terhadap siswa/kelompok siswa yang berhasil melakukan percobaan dengan baik, (3) kegiatan penutup, pada tahap ini dilakukan kegiatan yang sifatnya untuk penenangan (refleksi). Beberapa kegiatannya yang dilakukan seperti melakukan refleksi dengan meminta siswa untuk merenungkan, menilai, dan menanggapi kegiatan pembelajaran yang telah dilakukan, memberikan tugas rumah (PR), dan selanjutnya memberikan kepada masing-masing siswa soal-soal tes hasil belajar untuk mendapatkan data tentang hasil belajar siswa setelah diadakan tindakan (penilaian otentik).

Pada tahap ini dilaksanakan observasi terhadap pelaksanaan tindakan. Tujuan diadakannya observasi adalah untuk mengetahui langkah-langkah pembelajaran yang mana sudah sesuai dengan rencana, diperbaiki, atau dihilangkan dalam proses pembelajaran selanjutnya, sehingga hasil belajar matematika siswa kelas I SDN 6 Tianyar benar-benar dapat meningkat. Setelah diadakan pengamatan dilanjutkan dengan pemberian tes hasil belajar untuk dijawab oleh masing-masing siswa. 
Setelah dilakukan penskoran terhadap hasil tes belajar tersebut, diperoleh sebaran skor sebagai berikut.

Tabel 3. Data Skor Hasil Belajar Matematika Siswa Kelas I SD Negeri 6 Tianyar Tahun 2017/2018, Siklus II

\begin{tabular}{ccc}
\hline No & No Kode Siswa & Skor \\
\hline 1. & 001 & 60 \\
2. & 002 & 60 \\
3. & 003 & 70 \\
4. & 004 & 70 \\
5. & 005 & 60 \\
6. & 006 & 70 \\
7. & 007 & 80 \\
8. & 008 & 60 \\
9. & 009 & 60 \\
10. & 010 & 70 \\
11. & 011 & 70 \\
12. & 012 & 80 \\
13 & 013 & 60 \\
14 & 014 & 60 \\
& Jumlah & 930 \\
& Rata-Rata & 66 \\
& Skor tertinggi & 80 \\
\hline
\end{tabular}

Menyajikan Data dalam Bentuk Grafik Polygon

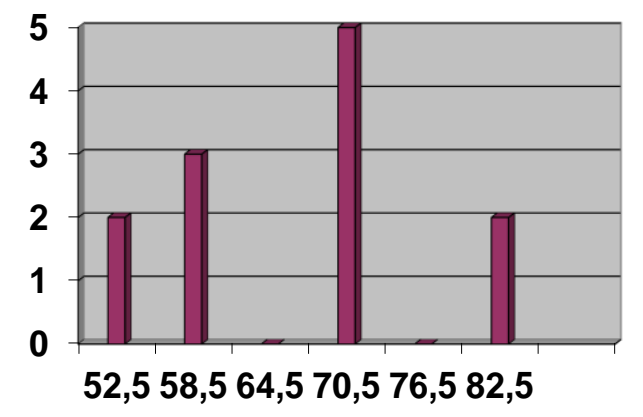

Gambar 2. Grafik Polygon Hasil Belajar Matematika Siklus II

Berdasarkan penyajian grafik di atas dapat dianalisis bahwa $\mathrm{M}<\mathrm{Mo}=$ Me atau 66,5 $<70,5=$ 70,5. Bentuk kurva di atas menunjukkan kurva juling negatif, yang artinya sebagian besar skor hasi belajar matematika kelas I cenderung tinggi.

Mengkaji hasil belajar matematika siswa kelas I pada siklus II, dapat dideskripsikan sebagai berikut. Skor hasil belajar yang diperoleh dari 14 orang siswa adalah dua orang siswa memperoleh skor pada interval 80 - 89 berada pada kategori baik, dan tiga orang siswa memperoleh skor pada interval 65 - 79 berada pada kategori cukup, Tujuh orang siswa memperoleh skor pada interval 55-64 berada pada kategori kurang, dan dua orang siswa memperoleh skor pada interval 0 - 54 berada pada kategori sangat kurang. Sedangkan tingkat hasil belajar rata-rata siswa kelas IV siklus II sebesar 66,5 ternyata berada dalam kategori cukup. Mencermati hasil analisis data hasil belajar matematika siswa kelas I SDN 6 Tianyar di atas, selanjutnya dilakukan refleksi terhadap penggunaan pendekatan pembelajaran kontekstual dalam pembelajaran matematika.

Berdasarkan hasil analisis data siklus II dapat dirumuskan beberapa refleksi yaitu (1) hasil belajar matematika siswa kelas I melalui penggunaan pendekatan pembelajaran kontekstual dalam pembelajaran menunjukkan hasil yang sangat baik dan terjadi peningkatan rata-rata hasil belajar dari siklus I sampai siklus II sebesar 6,33 yakni 66,5 - 60,17 $=6,33$, (2) kemampuan guru dalam membimbing dan memfasilitasi kegiatan pembelajaran harus ditingkatkan dan menindaklanjuti terhadap siswa yang 
mengalami masalah dalam pencapaian skor hasil belajar, sehingga nantinya pencapaian skor hasil belajar siswa bersangkutan dapat meningkat, dan (3) faktor penguasaan bahasa masih menjadi kendala bagi siswa dalam mengungkapkan gagasan atau ide yang dimiliki, sehingga muncul rasa tidak percaya diri dan akhirnya malu untuk mengungkapkannya.

Penerapan pendekatan kontekstual dalam pembelajaran siklus I telah dilakukan dengan cukup baik. Pelaksanaan pembelajaran siklus I telah berhasil meningkatkan hasil belajar siswa di bandingkan dengan hasil belajar siswa pada tahap pre-test. Hal ini dapat terlihat dari pencapaian hasil belajar sebesar 60,17 Berdasarkan analisis data hasil belajar yang dikumpulkan dari kegiatan penelitian pra siklus sampai kegiatan pelaksanaan tindakan pada siklus I, rata-rata hasil belajar menunjukkan adanya peningkatan. Berdasarkan hasil analisis data siklus I hasil belajar matematika siswa kelas I melalui penggunaan pendekatan pembelajaran kontekstual dalam pembelajaran menunjukkan hasil yang sangat baik dan terjadi peningkatan rata-rata hasil belajar dari pra siklus sampai siklus I sebesar 9,34 yakni 60,17 - 50,8 Namun berdasarkan tingkat hasil belajar siswa masih berada pada katagori kurang (persentase 55 - 64).

Banyak kendala atau hambatan yang ditemukan dalam penerapan pendekatan pembelajaran kontekstual. Kendala-kendala yang ditemui dalam pelaksanaan tindakan siklus I antara lain: (1) siswa masih bingung menentukan pecahan senilai maupun urutan pecahan, (2) Siswa kurang berani menyampaikan pertanyaan dalam kegiatan tanyajawab, (3) siswa kurang mampu menggunakan waktu secara efektif dalam kegiatan menemukan, Kemampuan siswa mengkaitkan materi pelajaran dengan kegiatan sehari-hari masih kurang. Dalam belajar siswa masih berpatokan pada contoh-contoh yang ada di buku. Hal ini disebabkan karena sebelumnya siswa terbiasa dengan pembelajaran konvensional dan peneliti dalam membantu siswa membuat hubungan antara materi dengan kehidupan sehari-hari masih kurang. Menurut Nurhadi, dkk (2004), salah satu peran guru adalah melaksanakan pembelajaran dengan memberikan motivasi kepada siswa untuk mengkaitkan materi yang sedang dipelajari dengan fenomena kehidupan sehari-hari. Dalam hal ini peran peneliti sebagai motivator dan fasilitator masih sangat kurang sehingga siswa belum mampu mengaitkan materi pelajaran dengan kegiatan sehari-hari

Berdasarkan kendala tersebut di atas diputuskan untuk memperbaiki beberapa masalah pada pembelajaran siklus II. Perbaikan yang dilakukan antara lain: (1) memberikan penjelasan disertai penggunaan media yang lebih banyak dalam belajar, (2) memotivasi siswa agar mau mengungkapkan gagasannya baik melalui bertanya, menjawab pertanyaan teman atau guru, dan menanggapi suatu masalah melalui pertanyaan-pertanyaan terbuka, (3) memantau dan membimbing siswa dalam kegiatan menemukan, bila siswa mengalami masalah atau kemacetan akan cepat termotivasi, (4) mengadakan bimbingan yang lebih kepada kelompok siswa yang mengalami kemacetan dalam melakukan percobaan.

Penerapan pendekatan kontekstual dalam pembelajaran siklus II telah dilaksanakan dengan baik, dan berhasil meningkatkan hasil belajar siswa di bandingkan dengan hasil belajar siklus I. Berdasarkan hasil analisis data siklus II, hasil belajar matematika siswa kelas 1 melalui penggunaan pendekatan pembelajaran kontekstual dalam pembelajaran menunjukkan hasil yang sangat baik dan terjadi peningkatan rata-rata hasil belajar dari siklus I sampai siklus II sebesar 6,33 yakni 66,5 - 60,17. Berdasarkan tingkat hasil belajar siswa sudah berada pada katagori cukup (persentase 65 - 79 ).

Berdasarkan hasil yang telah dicapai, ternyata penerapan pendekatan kontekstual dalam pembelajaran bilangan pecahan dapat meningkatkan hasil belajar siswa SD Negeri 6 Tianyar. Hal ini disebabkan melalui pendekatan pembelajaran kontekstual, guru menghadirkan situasi dunia nyata ke dalam kelas dan mendorong siswa membuat hubungan antara pengetahuan yang dimiliki dengan penerapanya dalam kehidupan sehari-hari. Dengan konsep belajar demikian siswa lebih mudah dalam memahami materi pelajaran karena materi yang diajarkan mereka pelajari merasa dekat dengan hal-hal yang pernah dialami dalam kehidupan sehari-hari. Sesuai dengan pendapatnya John Dewey (dalam Nurhadi, dkk, 2004) bahwa siswa akan belajar dengan baik apabila mereka mempelajari hubungan dengan yang telah mereka pelajari. Meskipun dalam pembelajaran siklus II hasilnya meningkat namun masih banyak yang perlu diperbaiki, agar hasil belajar siswa tetap mengalami peningkatan.

Hasil penelitian ini menunjukkan bahwa penggunaan pendekatan pembelajaran kontekstual dalam pembelajaran matematika dapat meningkatkan hasil belajar. Peningkatan hasil belajar tersebut ditengarai karena beberapa faktor seperti: (1) siswa terkondisi untuk mengalami proses pembelajaran tahap demi tahap sesuai dengan dunianya dan pengetahuan yang telah dimilikinya, (2) pembelajaran yang diikuti lebih bersifat alamiah, karena langsung berhadapan dengan lingkungannya, (3) siswa dapat mengkonstruksi sendiri pengetahuannya melalui bertanya, menemukan sendiri, dapat bekerjasama dengan orang lain/teman, dapat mencontoh dari pemodelan, sehingga siswa menjadi lebih percaya diri dan senang dalam belajar, (4) pengetahuan tidak diperoleh dengan menerima begitu saja dari guru, tetapi diperolehnya dari pengalaman sendiri, hal ini membuat pengetahuan yang didapat lebih terstruktur 
dalam otaknya, sehingga bila diberikan masalah/soal lain yang topiknya sama siswa akan mampu menyelesaikannya.

\section{Simpulan Dan Saran}

Berdasarkan analisis data hasil penelitian yang diuraikan dalam bab I dapat disimpulkan bahwa pembelajaran matematika dengan pendekatan kontekstual terbukti dapat meningkatkan hasil belajar matematika siswa kelas I semester I SD Negeri 6 Tianyar tahun ajaran 2017/2018, khususnya pada topik "Bilangan Pecahan." Hal ini dapat dilihat dari adanya peningkatan hasil belajar matematika siswa pada setiap siklus. Berdasarkan pelaksanaan pembelajaran siklus I hasil belajar yang dicapai siswa sebesar $60,17 \%$, tingkat hasil belajar berada pada 55 - 64 termasuk katagori kurang. Setelah dilaksanakan siklus II hasil belajar siswa yang dicapai sebesar 66,5\%, tingkat hasil belajar berada pada 65 - 76 termasuk katagori cukup. Jadi dari siklus I ke siklus II terdapat peningkatan hasil belajar sebesar $6,33 \%$. Peningkatan hasil belajar tersebut disebabkan oleh penggunaan pendekatan pembelajaran kontekstual secara efektif dalam pembelajaran matematika ternyata mampu mempermudah siswa dalam memahami materi pembelajaran. Siswa yang semula sangat sulit dalam memahami materi pembelajaran, menjadi lebih mudah memahaminya.

Berdasarkan simpulan seperti tersebut di atas diajukan saran-saran sebagai berikut: 1) Kepada para siswa disarankan agar membiasakan diri untuk melaksanakan tugas yang diberikan guru, serta berani menjawab pertanyaan yang diberikan guru dengan baik dan berani secara kritis menanyakan kepada guru hal-hal yang belum dipahami, 2) Kepada para guru disarankan agar dalam pengelolaan proses pembelajaran lebih mengupayakan pemilihan dan penggunaan pendekatan pembelajaran yaitu menggunakan pendekatan pembelajaran kontekstual, agar siswa memahami materi pembelajaran melalui pengalaman sendiri dan sesuai dengan dunia nyata peserta didik serta materi yang dipelajari tidak verbalis, 3) Kepada Kepala Sekolah agar memberikan perhatian, kesempatan, motivasi, dan memfasilitasi upaya guru dalam penggunaan pendekatan pembelajaran yang invatif diantaranya pendekatanl pembelajaran kontekstual sehingga dapat meningkatkan kualitas belajar siswa dan akhirnya dapat meningkatkan hasil belajarnya.

\section{Daftar Rujukan}

Agung. 1999. Metodologi Penelitian Pendidikan. Singaraja: STKIP

Depdiknas. 2004. Kurikulum 2004, Standar Kompetensi Mata Pelajaran Kelas IV. Jakarta: Depdiknas.

Depdiknas. 2003. Pendekatan Kontekstual (Contextual teaching and learning), Jakarta : Ditjen Dikdasmen.

Dibia, dkk. 2007. Pendidikan Bahasa Indonesia 2. Singaraja: FIP Undiksha.

Dimyati dan Mudjiono. 1999. Belajar dan Pembelajaran. Jakarta: Rineka Cipta.

Effendi, L.A., 2012. Pembelajaran matematika dengan metode penemuan terbimbing untuk meningkatkan kemampuan representasi dan pemecahan masalah matematis siswa SMP. Jurnal Penelitian Pendidikan, 13(2), pp.1-10.

Hudoyo,Herman. 1990. Strategi Belajar Mengajar Matematika. Malang: IKIP Malang.

Komalasari, K . 2010. Pembelajaran Kontekstual, Konsep dan Aplikasi, Bandung: Repika Aditama

Nochi, dan Nasution. 1994. Psikologi Pendidikan. Jakarta: Depdikbud

Nurhadi, dkk. 2004. Penerapan Kontekstual Dan Penerapannya Dalam KBK. Malang: Universitas Negeri Malang.

Oemar Hamalik. 2006. Proses Belajar Mengajar. Bandung: Bumi Aksara.

Purwanto, Ngalim,M. 1993. Media Pengajaran. Bandung: Sinar Baru 
Rosnawati, R., 2013. Kemampuan penalaran matematika siswa SMP Indonesia pada TIMSS 2011. In Prosiding Seminar Nasional Penelitian, Pendidikan dan Penerapan MIPA, Fakultas MIPA, Universitas Negeri Yogyakarta (Vol. 18).

Saefudin, A.A., 2012. Pengembangan kemampuan berpikir kreatif siswa dalam pembelajaran matematika dengan pendekatan pendidikan matematika realistik indonesia (PMRI). Jurnal Al Bidayah, 4(1).

Siagian, R.E.F., 2015. Pengaruh minat dan kebiasaan belajar siswa terrhadap prestasi belajar matematika. Formatif: Jurnal Ilmiah Pendidikan MIPA, 2(2).

Sudrajat, Akhmad. 2008. Beda Strategi, Model, Pendekatan, Metode, dan Teknik $\quad$ Pembelajaran (http://smacepiring.wordpress.com/)

Sunaryo. 1989. Strategi Belajar Mengajar Ilmu Pengetahuan Sosial. Cet. 2 Malang: IKIP Malang

Supriyanto, B., 2014. Penerapan Discovery Learning Untuk Meningkatkan Hasil Belajar Siswa Kelas VI B Mata Pelajaran Matematika Pokok Bahasan Keliling Dan Luas Lingkarandi Sdn Tanggul Wetan 02kecamatan Tanggul Kabupaten Jember. Pancaran Pendidikan, 3(2), pp.165-174.

Suyanto. 1997. Pengenalan Penelitian Tindakan Kelas. Jakarta: BP3SD, Diijen Dikti. Depdikbud.

Sudjana,nana 1992. Dasar-Dasar Proses Belajar Mengajar. Bandung: Sinar Baru, Algensindo.

Tabrani, A . Rusyan. 1993. Proses Belajar Mengajar Yang Efektif. Bandung: Bina Budaya.

Tantra. 2004. Strategi Peningkatan Kualitas Pembelajaran. Singaraja: Makalah Pelatihan Guru Khusus (Pemandu) SD/MI di Kabupaten Karangasem.

Widjajanti, D.B., 2009, December. Kemampuan pemecahan masalah matematis mahasiswa calon guru matematika: apa dan bagaimana mengembangkannya. In Seminar Nasional Matematika dan Pendidikan Matematika (Vol. 5). 